\title{
ROS Scavenging Effect and Cell Viability of Opuntia humifusa Extract on Osteoblastic MC3T3-E1 Cells
}

\author{
Hyun-Jung Hwang ${ }^{1}$, Bok-Mi Jung ${ }^{2}$ and Mihyang Kim* \\ ${ }^{1}$ Department Food and Nutrition, Silla University, Busan 617-738, Korea \\ ${ }^{2}$ Major in Food Science and Nutrition, Chonnam National University, Jeonnam 550-749, Korea
}

Received November 3, 2011 /Revised December 13, 2011 /Accepted December 14, 2011

\begin{abstract}
In this study, the effect of the Opuntiahumifusa extracts on proliferation, alkaline phosphatase (ALP) activity, collagen synthesis and ROS level of a cell was investigated using an osteoblast. Opuntiahumifusawas separated intoOpuntiahumifusapeel (OH-P), seed (OH-Se) and stem (OH-St). These were subjected to extraction by using hot water and ethanol. The proliferation of the MC3T3-E1 osteoblastic cells that were treated with OH-Se water extract were increased by approximately $120 \%$. Regarding the effects of OH-Se on ALP activity, the $50 \mu \mathrm{g} / \mathrm{ml}$ ethanol extract group showed the highest activity. The synthesis of collagen increased significantly in response to treatment with OH-Se water extract. The ROS scavenging effects of Opuntiahumifusawere investigated for involvement of oxidativedamage, cell culture and staining. Also, when $\mathrm{OH}-\mathrm{Se}$ water extract $100 \mu \mathrm{g} / \mathrm{ml}$ was added, the ROS level decreased by $54 \%$. These results indicate that Opuntiahumifusa extracts have an anabolic effect on bone through the promotion of osteoblastic differentiation, suggesting that it could be used for the treatment of common metabolic bone diseases.
\end{abstract}

Key words : Opuntiahumifusa, MC3T3-E1 cell, alkaline phosphatase, collagen synthesis, ROS level

\section{서 론}

인간의 인생 주기 중 중년기는 신체 기관의 기능 감퇴, 노화, 호르몬 변화로 여러 가지 건강 문제를 경험하게 되는데, 특히 골다공증은 여성의 폐경과 관련된 에스트로겐 호르몬 결핍으 로 발생하는 질환으로 알려져 있다[34]. 2010년 발표한 건강보 험심사청구데이터에 의하면 연간 인구대비 골다공증의 의사 진단 환자비율은 매년 $8.7 \%$ 씩 증가하고 있으며, 2005년부터 2008년까지 50세 이상의 골다공증성 골절의 발생은 연평균 $3.8 \%$ 씩 발생수가 증가하는 양상이 나타났다[7]. 대표적인 골 대사 질환인 골다공증은 효과적인 치료 방법이 없기 때문에 예방이 가장 중요하며, 현재까지 알려진 최선의 치료는 성장 기 동안의 최대 골 질량(peak bone mass)을 극대화하고 골 손실 위험 인자를 피하는 것이라고 한다[2]. 현재 골다공증의 예방과 치료에 가장 많이 이용되고 있는 방법은 비타민 D의 보충과 함께 에스트로겐, 칼시토닌, 선택적 세로토닌 재흡수 억제제 및 비스포스포네이트 등의 처방이 알려져 있다[1].

조골세포는 골조직의 세포 외 기질을 합성하고, 기질의 침 착과 석회화를 조절하는 골격계의 주된 세포이며[29], 연골세 포(contracts), 간엽줄기 분화세포(myocytes) 및 지방세포 (adipocytes)로 분화가 가능한 골 기질 합성과 석회화에 관여 하는 세포이다[13]. 세포막에는 당단백 효소인 alkaline phos-

\section{*Corresponding author}

Tel : +82-51-999-5620, Fax : +82-51-999-5457

E-mail : mihkim@silla.ac.kr phatase (ALP)가 존재하고 있으며, 이는 기질 특이성과 염기 성 $\mathrm{pH}$ 에서 최적의 활성을 나타내고 세포의 외막과 석회화 조 직의 기질 소포에서 높은 농도로 존재한다[6]. Collagen은 경 섬유 단백질로써, 결합조직에 광범위하게 분포되어 있으며 [23], 여러 cytokine의 분비를 통해 파골세포의 활성을 조절하 는 기능을 담당하고 있다[25]. 이들 cytokine은 골세포 자체로 부터 합성되어 골 기질 내로 함입되고, 생물학적으로 활성화 된 형태로 유리된다고 알려지고 있다[11]. 또한 활성화된 조골 세포는 골 기질을 형성하는데 collagen, osteocalcin, osteopontin 및 bone sialoprotein과 같은 물질을 합성하여 석회화 과정에 중요한 역할을 한다[20]. 골세포의 배양법은 골의 대사, 골세포의 생성 및 분화 등의 연구와 골 대사에 미치는 효과, 식품유래 천연물질의 골 대사 조절물질을 검색하는데 비교적 간편하면서 유용한 방법으로 알려져 있다[6,32]. 본 연구에 사 용한 mouse calvaria 유래의 MC3T3-E1 세포는 in vivo 골 형성 과정에서 나타나는 세포의 증식, 분화, 석회화 등 골아세포와 유사한 대사적 특징을 가지고 있으므로, 골세포의 세포 활성 과 관련된 연구에서 유용하게 이용되어 왔다[14].

최근 질병 치료, 예방 및 건강증진 등 생리활성을 가지는 기능성 물질은 식품 - 의약품 시장에서 높은 성장가능성을 갖 는 산업분야로 떠오르고 있으며, 특히 천연물 유래 물질은 화 학 합성품에 비해 각종 질병에 효과적인 경우가 많고 낮은 독성과 부작용에 대한 인식으로 높은 소비자 선호도를 보이고 있다[23].

본 연구에 사용된 천년초 선인장(일명 손바닥 선인장)은 우 
리나라에서 자생하는 'Opuntia'속 선인장 중 제주도 등지에서 생존하는 다년생 현화식물이다[38]. 천년초 선인장은 줄기의 길이가 $30 \sim 40 \mathrm{~cm}$, 영하 $20^{\circ} \mathrm{C}$ 의 혹한에서도 자체수분을 절반 이하로 감소시켜 얼어 죽지 않고 생명력을 유지하는 특성을 갖고 있어 지역특화산업을 위한 신 작물로의 개발이 유망 시 되고 있다. 예로부터 본초강목과 중앙대사전에 의하면, 선인 장 즙을 마시면 변비치료, 이뇨효과, 장 운동의 활성화 및 식욕 증진 효능이 있고, 피부질환 및 화상치료에도 사용되어 왔다 고 한다[22]. 하지만 이러한 효능에도 불구하고 아직 천년초에 대한 연구는 열매와 줄기를 이용한 일반성분 분석과 무기질 함량에 대한 분석 $[17,36]$ 등 구성성분에 관한 연구가 대부분이 다. 또한 생리활성에 관한 연구로는 천년초 줄기를 이용한 항 산화 및 항비만 활성검증[15] 및 사염화탄소를 처치한 흰쥐에 서의 간 보호 효과[33] 등이 이루어졌으며, 천년초가 골 대사에 미치는 영향에 관한 연구는 전무한 실정이다.

따라서 본 연구에서는 MC3T3-E1 세포를 이용하여 천년초 추출물이 조골세포의 증식에 미치는 영향, 조골세포의 활성과 분화 인자인 ALP 활성, 골 형성을 위한 필수 인자인 collagen 합성에 미치는 영향 및 조골세포 세포사의 주요 인자인 ROS 에 미치는 영향에 대해 검토하였다.

\section{재료 및 방법}

\section{세포배양}

본 실험에서는 경희대학교 의과대학 내분비 연구실에서 분 양 받은 mouse calvaria osteoblast cell 인 MC3T3-E1 세포를 사용하였다. 세포는 $10 \% \mathrm{FBS}$ (Gibco)와 $1 \%$ penicillin (Gibco) 를 첨가한 a-MEM 배지(Gibco BRL, Grand islane, N.Y., USA) 로 2-3일 마다 교환하면서 $37^{\circ} \mathrm{C}, 5 \%$ 의 $\mathrm{CO}_{2}$ incubator에서 배양 하여 사용하였다. 분화유도를 위해 $5 \mathrm{mM} \beta$-glycerol phosphate (Sigma Chem. Co., St. Louis. MO., USA)와 $50 \mathrm{mg} / \mathrm{ml}$ 의 vitamin C (Sigma)를 첨가하여 분화유도 배지로 사용하였 으며, 3 일마다 배지를 교환하였다.

\section{추출물 제조}

본 실험에서 사용한 천년초(Opuntia humifusa, $\mathrm{OH}$ )의 열매 와 줄기는2010년 10월 전남 여수시 돌산읍 라파엘 농장에서 구입하여 물로 4 5회 씻어 가시와 불순물을 제거하였다. 세 척된 천년초는 열매와 줄기 부분을 분리 한 뒤 동결 건조하여 열매는 다시 씨와 껍질로 분리 하였다. 분리된 천년초의 껍질, 씨 그리고 줄기는 분쇄하여 실험에 사용하였으며 추출용매의 극성을 달리하기 위하여 물과 $70 \%$ 에탄올을 추출용매로 사용 하였다(Table 1). $100 \mathrm{~g}$ 의 건조된 시료에 물과 $70 \%$ 에탄올 2 1 를 각각 가해 $80^{\circ} \mathrm{C}$ 에서 4 시간 추출하여 농축하고 건조하여 분말화하였다. 동결 건조하여 얻은 천년초 추출물 분말을 각 각 에탄올로 용해하여 $1,10,50,100 \mu \mathrm{g} / \mathrm{ml}$ 농도로 조절하여
Table 1. Experimental design of Opuntia humifusa

\begin{tabular}{llll}
\hline \multirow{2}{*}{ Solvents } & \multicolumn{3}{c}{ Gorups } \\
\cline { 2 - 4 } & Seed & Peel & Stem \\
\hline Hot water & OH-SeW & OH-PW & OH-StW \\
Ethanol & OH-SeE & OH-PE & OH-StE \\
\hline
\end{tabular}

$0.2 \mu \mathrm{m}$ membrane filter로 여과한 후 실험에 사용하였다.

\section{세포증식 유도}

시료의 농도 별 처리에 따른 조골세포의 세포 증식은 Green 등의 방법에 따라 3-(4,5-dimethylthiazol-2-yl)-2,5-diphenyl tetrazolium bromide (MTT, sigma) 시약의 환원 정도를 측정 하는 MTT assay 방법을 사용하여 측정하였다. MC3T3-E1 세 포를 $0.4 \%$ tryphan blue 염색법을 이용하여 세포 수를 $1 \times 10^{5}$ cell $/ \mathrm{ml}$ 로 조정하여 96 well plate에 platting 한 후, 농도 별로 준비된 천년초 추출물을 $20 \mu \mathrm{l}$ 씩 첨가하여 $37^{\circ} \mathrm{C}, 5 \%$ 의 $\mathrm{CO}_{2}$ incubator에서 48 시간 배양하였다. 이때 대조군으로는 천년초 추출물 대신 에탄올을 $20 \mu 1$ 를 첨가하여 동일하게 배양하였다. 48 시간 배양 후 MTT $(5 \mathrm{mg} / \mathrm{ml})$ 시약을 $10 \mu \mathrm{l}$ 씩 각각의 well 에 첨가하고 $37^{\circ} \mathrm{C}, 5 \%$ 의 $\mathrm{CO}_{2}$ incubator에서 4 시간 더 배양하 였다. 배양 후 배지를 제거하고 DMSO (dimethyl sulfoxide)를 $100 \mu \mathrm{l}$ 씩 첨가하여 생성된 불용성의 formazan 결정을 용해시 킨 뒤 ELISA reader로 $550 \mathrm{~nm}$ 에서 흡광도를 측정하였으며, 세포 증식률은 천년초 추출물의 흡광도를 대조군의 흡광도에 대한 백분율로 나타내었다.

\section{Alkaline phosphatase (ALP) 활성}

MC3T3-E1 세포를 $1 \times 10^{5}$ cell $/ \mathrm{ml}$ 로 조정하여 96 well plate 에 platting 한 후, 농도 별로 준비된 천년초 추출물을 $20 \mu \mathrm{l}$ 씩 첨가한 후 $37^{\circ} \mathrm{C}, 5 \%$ 의 $\mathrm{CO}_{2}$ incubator에서 48 시간 배양하였다. 48시간 배양 후 $\mathrm{PBS}$ 로 3 회 세척하고 $0.1 \%$ triton X-100을 20 ul씩 넣은 다음 $37^{\circ} \mathrm{C}, 5 \%$ 의 $\mathrm{CO}_{2}$ incubator에서 30 분간 lysis하 였다. Lysis된 cell의 상등액 $5 \mu 1$ 는 단백질 정량에 사용하였고, 나머지 상등액에 $20 \mu \mathrm{l}$ 의 $0.1 \mathrm{~N}$ glycine과 $100 \mu \mathrm{l}$ 의 100 $\mathrm{mM}$ p-nitrophenylphosphate (p-NPP)를 첨가한 후 $37^{\circ} \mathrm{C}, 5 \%$ 의 $\mathrm{CO}_{2}$ incubator에서 30 분간 반응시켰다. 반응 후 $0.1 \mathrm{~N}$ $\mathrm{NaOH}$ 로 반응을 정지하고 $200 \mu \mathrm{ll}$ 를 취해 $405 \mathrm{~nm}$ 에서 흡광도 를 측정하여 ALP 효소에 의해 p-nitrophenol로 전환된 양을 산출하였다. 세포수의 차이가 ALP 활성도에 영향을 미칠 수 있으므로 총 단백질 양을 측정하여 나누어 줌으로써 단위 세 포 수에 대한 ALP 활성도를 계산하였다.

\section{Collagen 측정 방법}

천년초 추출물을 첨가하여 배양한 MC3T3-E1 세포를 PBS 로 2회 세척한 후 Bouin's fluid (saturated picric acid:35\% formaldehyde:glacial acetic acid=15:5:1)로 1 시간 고정하였다. 
세척 후 건조하여 Sirius Red reagent $(1 \mathrm{mg} / \mathrm{ml}$ saturated picric acid)로1시간 염색(shaking)하고 $0.01 \mathrm{~N} \mathrm{HCl}$ 로 washing 한 후에 $0.2 \mathrm{ml}$ 의 $0.1 \mathrm{~N} \mathrm{NaOH}$ 에 녹여 ELISA reader로 550 $\mathrm{nm}$ 에서 흡광도를 측정하였다.

\section{ROS leverl측정}

MC3T3-E1 세포를 배양접시에 분주하여 배양한 후 80 $90 \%$ 포화되게 자라면 배지를 제거하여 $\mathrm{PBS}$ 로 세척한 후 tryp$\sin$ 을 처리하여 세포를 수확하였다. 수확한 세포는 원심분리 (1,100 rpm, 3분)하여 상층액을 제거한 후 hank's balanced saline solution (HBSS)을 넣어 세포를 부유시켰다. 이에 최종농 도가 $5 \mu \mathrm{M}$ 이 되도록 DCF-DA를 첨가하여 형 광발광을 막기 위해 conical tube로 감싼 후 $37^{\circ} \mathrm{C}$ 에서 2시간 shaking incubation하고 원심분리를 하여 HBSS를 제거한 후 PBS로 2희 세척하였다. 이후 PBS를 첨가하여 DCF-DA로 labelling된 세 포액을 마련하여 천년초 추출물을 농도별로 처리한 후 0.3 $\mathrm{mM} \mathrm{H}_{2} \mathrm{O}_{2}$ 를 투여하여 fluorescence spectrometer을 이용해 excitation $485 \mathrm{~nm}$, emission $530 \mathrm{~nm}$ 에서 측정하였다.

\section{통계처리}

연구결과 얻어진 자료를 SPSS 통계 프로그램을 사용하여 하위그룹 각각의 기술 통계치(mean, SD)를 산출하였다. 사후 검증은 Tukey 를 적용하였고 $a<0.05$ 수준에서 유의수준을 검 증하였다.

\section{결과 및 고찰}

\section{천년초 추출물의 제조}

천년초의 껍질, 씨, 줄기 분말로부터 열수와 에탄올로 추출 하여 건조 한 후의 결과를 Table 2에 나타냈다. 껍질 열수 추출 물의 경우, $100 \mathrm{~g}$ 으로부터 추출물 $35.2 \mathrm{~g}$ 을 획득하여 $35.2 \%$ 로 천년초 추출물 중 가장 높은 수율을 나타냈다. 씨 열수 추출물 의 경우에는 $27.8 \%$ 를, 줄기 열수 추출물은 $29.41 \%$ 의 수율을 나타냈었다. 껍질 에탄올 추출물의 경우, $28.7 \%$ 의 수율을 나타 냈으며 씨 에탄올 추출물은 $20.6 \%$, 줄기 에탄올 추출물은 $24.5 \%$ 의 수율을 나타내었다.

\section{조골세포에 대한 증식유도 효과}

MTT (3-(4,5-dimethylthiazol-2-yl)-2,5-diphenyl tetrazolium bromide) 분석은 탈수소 효소작용에 의해 노란색의 수용 성 기질인 MTT tetrazolium을 청자색의 formazan으로 환원 시키는 미토콘드리아의 능력을 이용하는 검사법으로 이 검사 법은 세포의 증식과 성장을 알아보는 대표적인 실험방법 중 하나로 살아있는 세포 수에 비례해서 흡광도를 나타낸다.

천년초 추출물의 농도 $(1,10,50,100 \mathrm{\mu g} / \mathrm{ml})$ 에 따른 조골 세포 성장에 미치는 영향을 MTT assay로 분석한 결과는
Fig. 1 과 같다. MC3T3-E1 세포에 천년초 열수 또는 에탄올 추출물 $10 \mu \mathrm{g} / \mathrm{ml}$ 이상 첨가한 모든 군에서 대조군과 비교 하여 유의적인 증식률을 나타내었다. 특히, $100 \mu \mathrm{g} / \mathrm{ml}$ 씨 열수 추출물을 첨가하였을 때, 대조군과 비교하여 가장 높 은 $120 \%$ 정도의 증식률을 나타내었다. 조골세포 증식과 관 련한 천연 식물의 연구에서 전[11]에 의하면 해조류인 톳 분 획물의 경우 대조군과 비교하여 유의적으로 증가하였고, 특 히 butanol 분획물에서 가장 높은 활성을 나타내었다. 본 연 구에서는 천년초 추출물을 사용하였으나, 톳 분획물과 거의 유사한 활성을 나타내어 골 형성 소재로써 활용 가능성이 충분히 있음을 확인하였다.

\section{Alkaline phosphatase (ALP) 활성에 미치는 영향}

염기성 인산분해 효소(Alkaline phosphatase; ALP)는 거의 모든 조직에 존재하며 특히 골조직에 존재하는 $\mathrm{ALP}$ 는 골 성 장이 활발히 일어날 때 그 활성이 증가한다[12]. 따라서 조골세 포 활성을 나타내는 biomaker로써[10], MC3T3-E1 조골세포 에서의 ALP 활성을 측정하여 천년초 추출물이 조골세포의 골 성장 활성에 미치는 영향을 검토하였다. 조골세포의 ALP 활성은 천년초 추출물을 10 50 $\mu \mathrm{g} / \mathrm{ml}$ 첨가하였을 때, 열수 및 에탄올 추출물 모두 대조군과 비교하여 유의적으로 증가하 였다(Fig. 2). 특히, 씨 에탄올 추출물을 $50 \mu \mathrm{g} / \mathrm{ml}$ 첨가하였을 때, $130 \%$ 이상의 활성을 나타내었다.

주로 세포막에 결합되어 존재하는 염기성 인산 분해효소는 기질 특이성과 염기성 $\mathrm{pH}$ 에서 최적의 활성을 나타내는 효소 로써 골세포 분화의 표지인자로 알려져 있다[36]. 따라서 씨 에탄올 추출물이 조골세포의 $\mathrm{ALP}$ 의 발현을 증가시켜 조골세 포의 분화에 영향을 줄 가능성을 제시하고 있다. 조골세포 배 양 시 첨가한 vitamin C와 $\beta$-glycerol phosphate는 ALP와 세 포 외 기질의 석회화에 영향을 미친다고 알려져 있으며 vita$\min$ C는 MC3T3-E1 세포에서 type I collagen 발현을 자극하 지는 않지만 세포외 기질에서 collagen 침착에는 반드시 필요 하며, 성숙세포에서 $\mathrm{ALP}$ 의 활성을 유도한다. B-glycerol phosphate는 vitamin C에 대해 상승효과를 보이며, 분화된 조골세포에서 collagen 축적이나 ALP 활성도를 더욱 증가시 킨다고 보고되고 있다[9]. 천년초의 성분을 분석한 결과 flavonoid 계열 중 flavanone 계통의 taxifolin [19] 등과 다량의

Table 2. Yields (\%) of hot water and ethanol extracts of Opuntia humifusa (unit : \%)

\begin{tabular}{ccc}
\hline \multirow{2}{*}{ Groups $^{1)}$} & \multicolumn{2}{c}{ Yields } \\
\cline { 2 - 3 } & Hot water & Ethanol \\
\hline OH-P & 35.2 & 28.7 \\
OH-Se & 27.8 & 20.6 \\
OH-St & 29.4 & 24.5 \\
\hline
\end{tabular}

${ }^{1)}$ Refer to Table 1. 


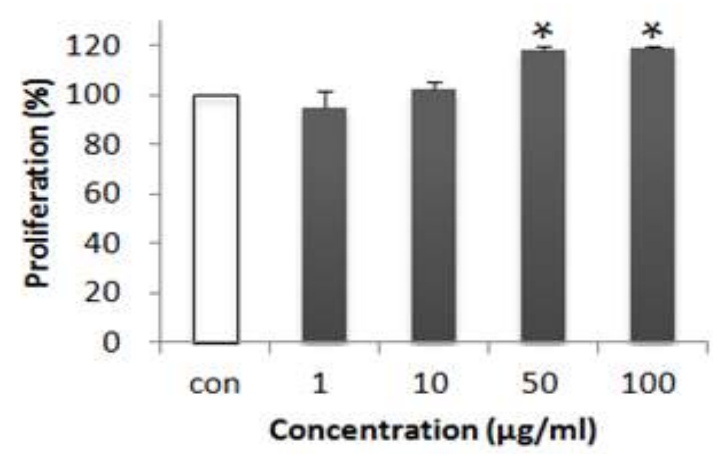

(a) OH-SeW

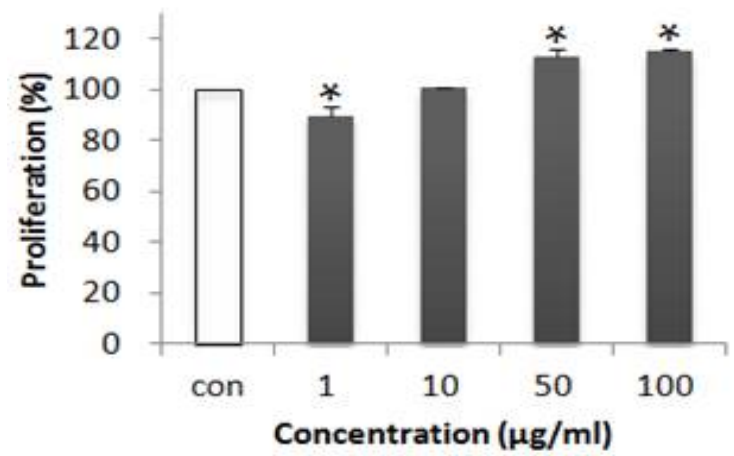

(c) OH-PW

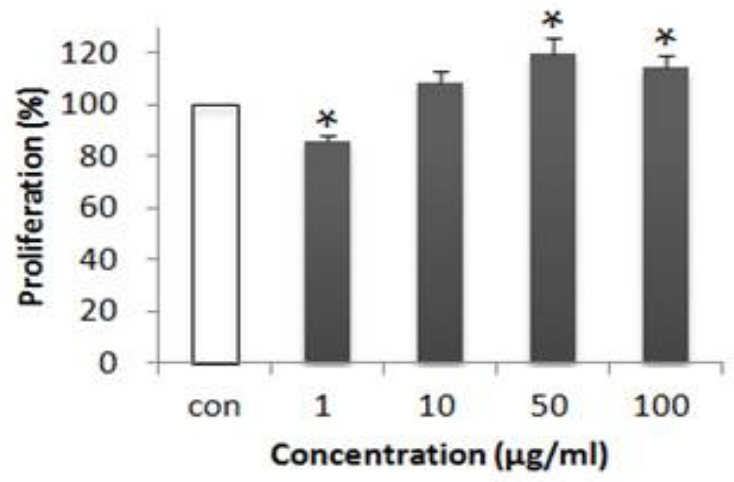

(e) OH-StW

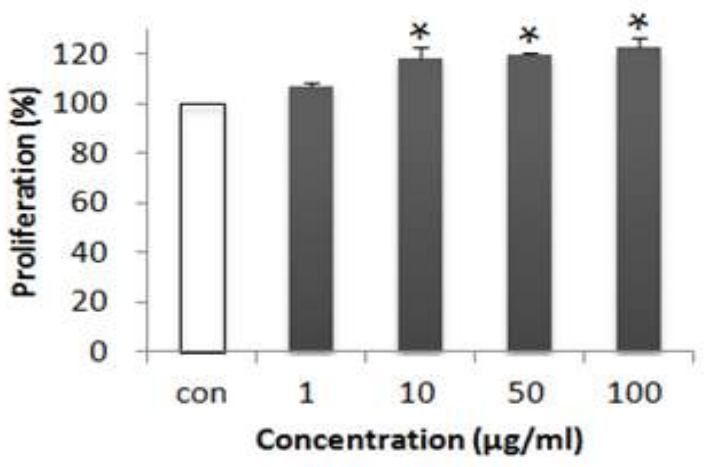

(b) OH-SeE

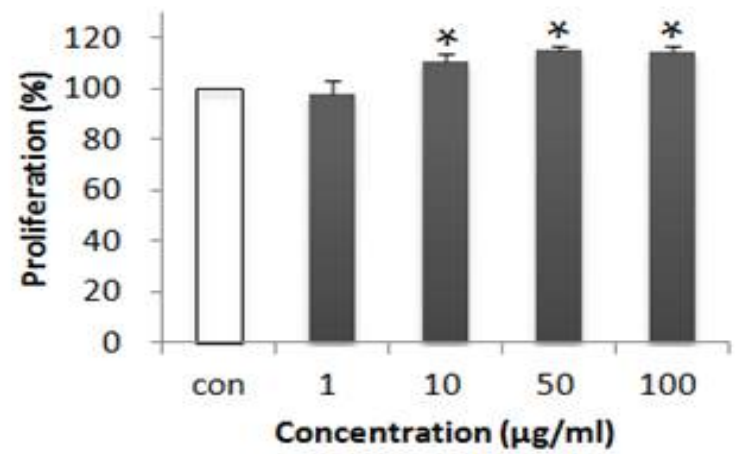

(d) OH-PE

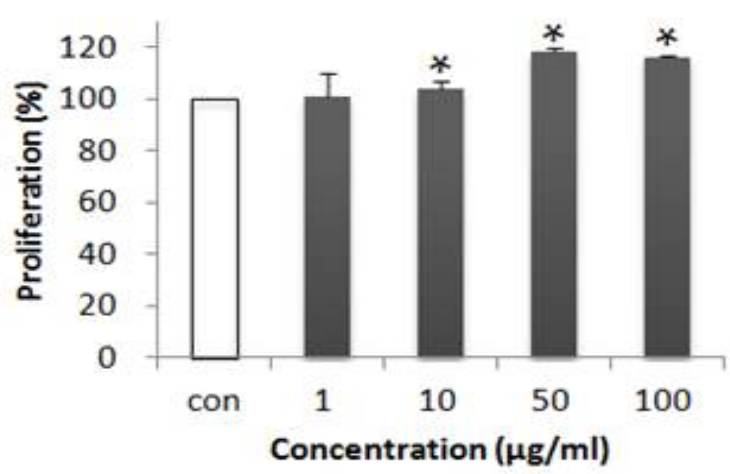

(f) OH-StE

Fig. 1. Effect of hot water and ethanol extracts of Opuntia humifusa on the proliferation of the MC3T3-E1 osteoblastic cells by the MTT assay. MC3T3-E1 cells were cultured with vehicles or various concentrations of Opuntia humifusa extracts. Data were expressed as percentage of control. Con; Opuntia humifusa extracts $0 \mu \mathrm{g} / \mathrm{ml},{ }^{*} p<0.05$ compared with control.

vitamin C가 함유되어 있다[39]는 보고가 있는데 이들 성분들 이 조골세포의 분화에 영향을 미치는 것으로 보인다. 이상의 결과로 황금 추출물[35], 아보카도 과피 및 씨 추출물[18]에서 조골세포의 ALP 활성을 증가시켰다는 보고와 유사하게 천년 초 추출물에서도 ALP 활성을 가짐을 확인하였다. ALP는 조골 세포의 분화에 발현되는 분화 표식인자이므로 이러한 결과는 조골세포의 ALP 발현을 증가시켜 조골세포의 분화에 영향을 줄 가능성을 제시했다. 따라서 천년초 씨, 껍질 및 줄기 추출물 은 조골세포 증식을 촉진 할 뿐만 아니라 ALP 활성을 높이는
소재로 생각 할 수 있다.

\section{조골세포의 collagen 합성에 미치는 영향}

골 형성이 이루어지는 과정은 type I collagen의 합성과 세포내의 과정 그리고 세포 외로 분비, 섬유질의 형성 및 collagen 기질의 성숙과 hydroxyapatite 형성 등의 단계를 밟는다 [37]. 조골세포에서 합성되는 type I collagen은 전체 골 단백 질의 85 90\%를 차지하며, 조골세포는 여러 가지 호르몬 국소 인자에 의해 조절되고 있다[4,5,30]. 대표적으로 부갑상선 호르 


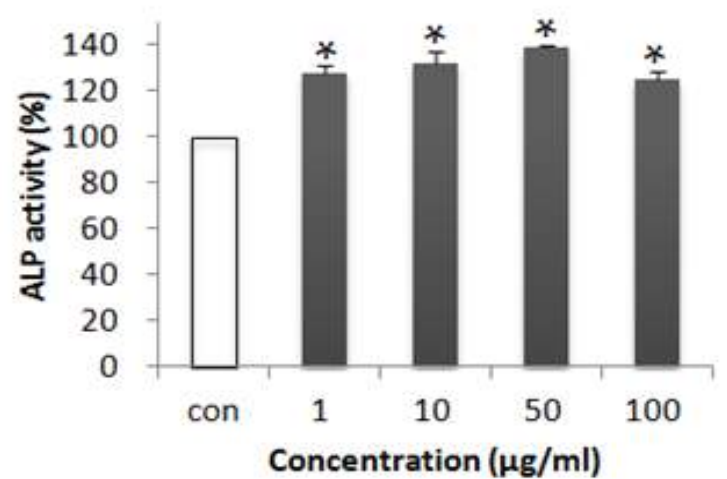

(a) $\mathrm{OH}-\mathrm{SeW}$

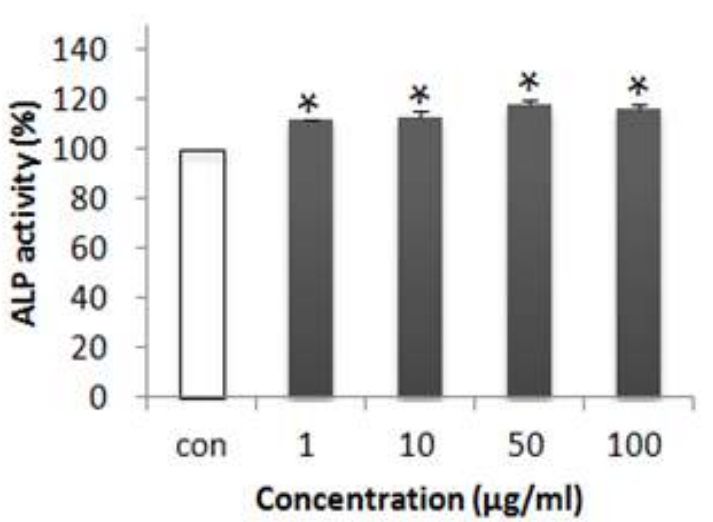

(c) $\mathrm{OH}-\mathrm{PW}$

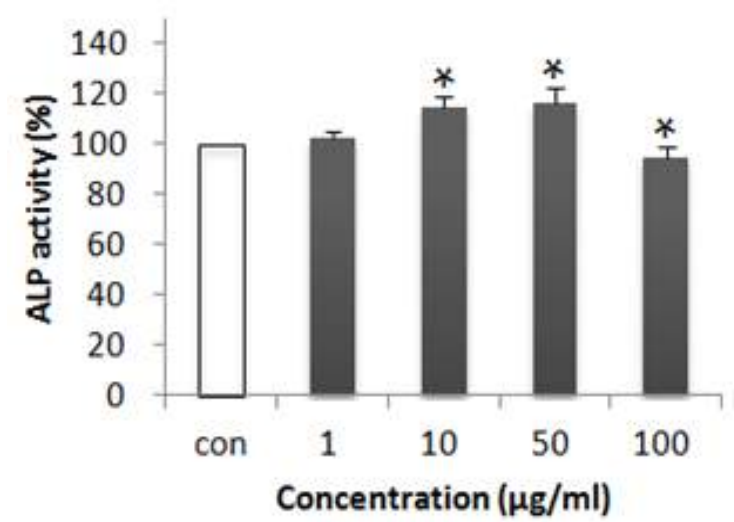

(e) OH-StW

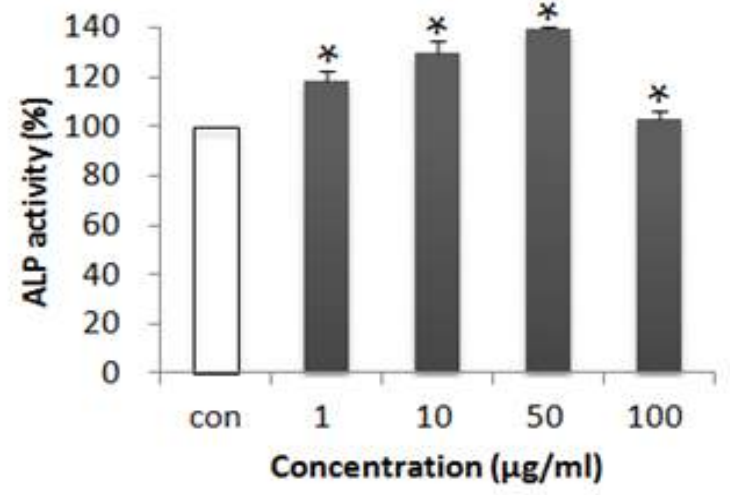

(b) OH-SeE

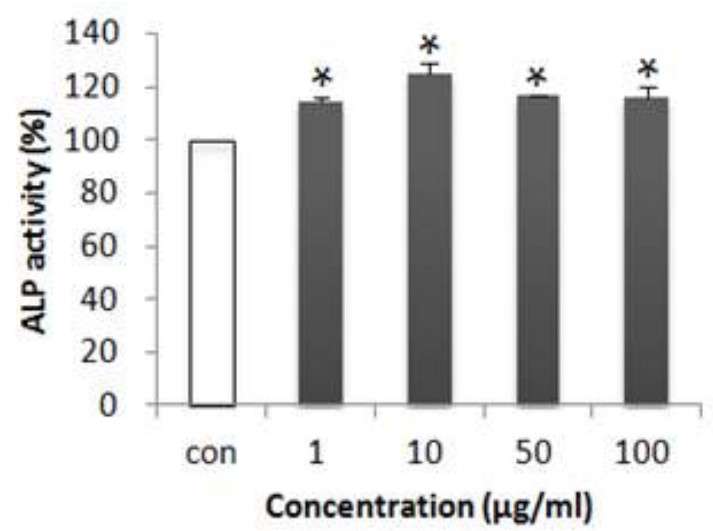

(d) OH-PE

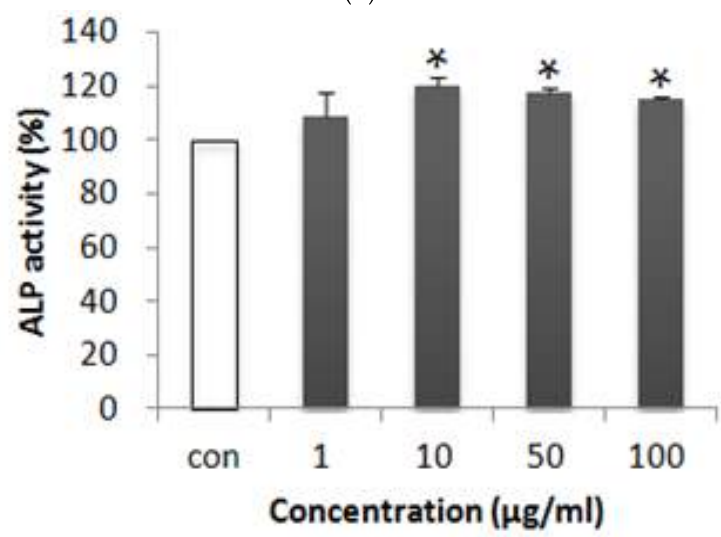

(f) OH-StE

Fig. 2. Effects of hot water and ethanol extracts of Opuntia humifusa on the alkaline phosphatase activities of the MC3T3-E1 osteoblastic cells during the differentiation. Data were expressed as percentage of control.Con; Opuntia humifusa extracts $0 \mu \mathrm{g} / \mathrm{ml},{ }^{*} p<0.05$ compared with control.

몬, 갑상선 호르몬, $1,25(\mathrm{OH})_{2} \mathrm{D}_{3}$, 성호르몬, insulin 등이 있고 국소인자로는 프로스타글란딘과 여러 종류의 cytokine 이 이 에 해당된다[4]. 뼈는 주로 collagen과 칼슘으로 구성되어 있으 며, 계속 성장하며 살아있는 조직이다. Collagen은 뼈에서 부 드러운 골격을 형성하는 단백질이고 인산칼슘이라는 미네랄 이 뼈의 골격을 강하고 단단하게 만들어 준다. 또한 collagen은 골조직의 유기물의 대부분을 차지하며, collagen이 적절하게
생성되지 못하는 조건에서는 골조직의 석회화가 일어나지 않 을 뿐만 아니라 ALP 활성 저하 및 osteocalcin 의 생성 또한 매우 감소하는 것으로 알려져 있다[31].

Fig. 3에 천년초 추출물이 조골세포의 collagen 합성능에 미치는 영향을 나타내었다. 천년초 추출물을 $10 ~ 100 \mu \mathrm{g} / \mathrm{ml}$ 첨가하였을 때, 대조군과 비교하여 유의적으로 증가된 collagen 합성능을 보였다. 특히, 씨 열수 추출물과 씨 에탄올 추출 


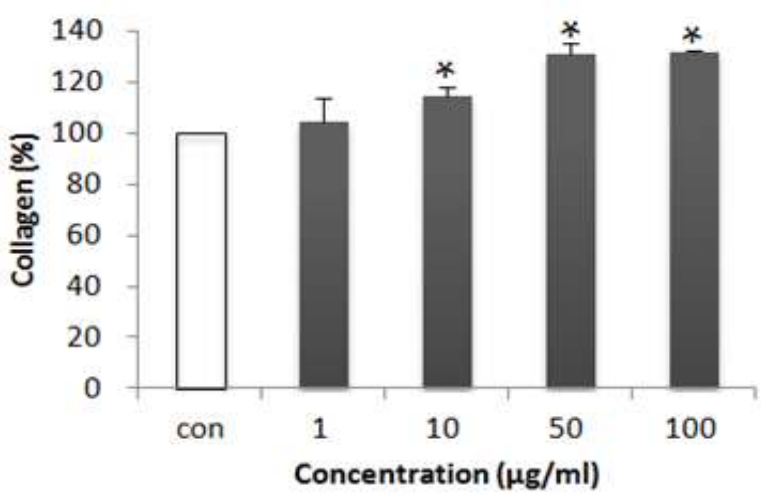

(a) OH-SeW

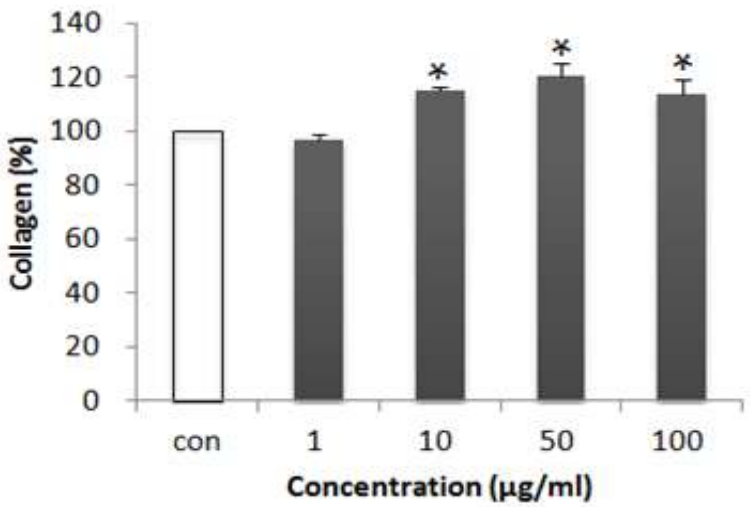

(c) OH-PW

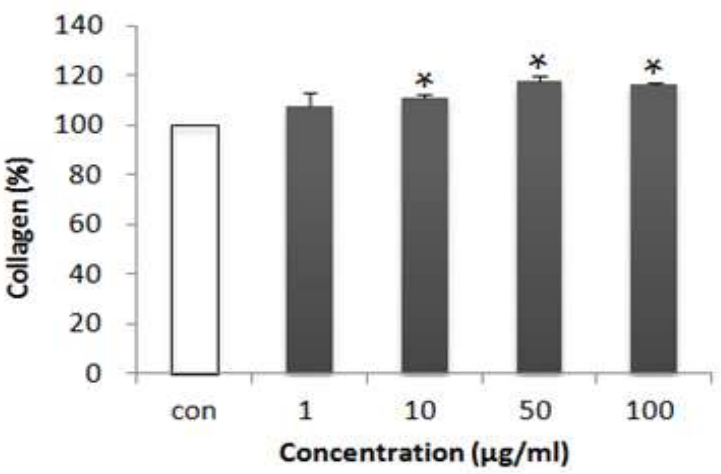

(e) OH-StW

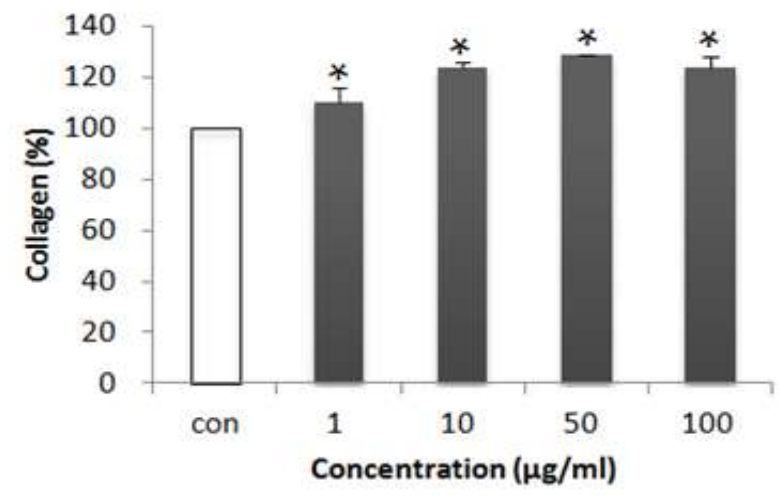

(b) OH-SeE

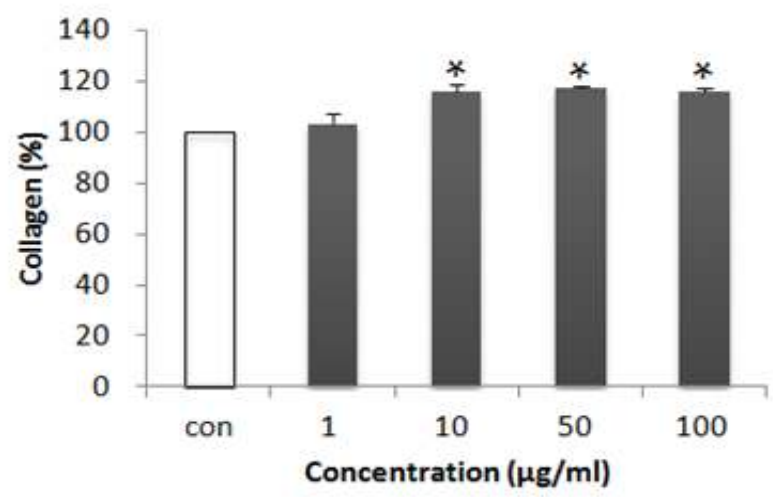

(d) OH-PE

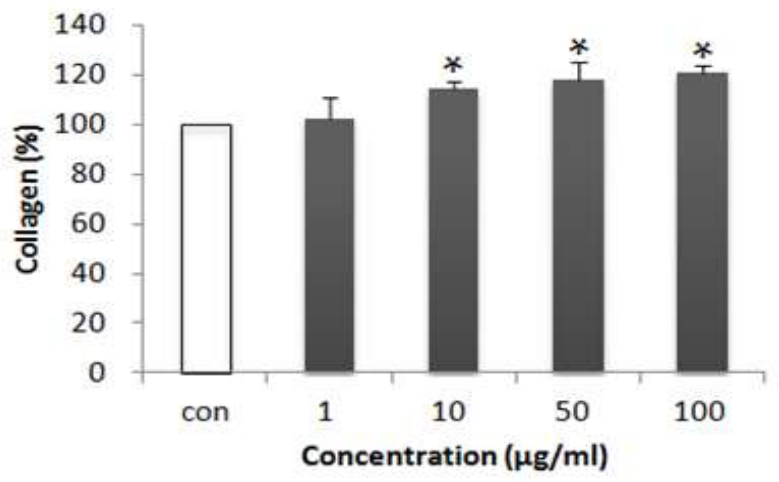

(f) OH-StE

Fig. 3. Effects of hot water and ethanol extracts of Opuntia humifusa on collagen content in bone of the MC3T3-E1 osteoblastic cells. Data were expressed as percentage of control. Con; Opuntia humifusa extracts $0 \mu \mathrm{g} / \mathrm{ml},{ }^{*} p<0.05$ compared with control.

물의 $50 \sim 100 \mu \mathrm{g} / \mathrm{ml}$ 농도에서 높은 합성능을 나타내었으며 그 중 씨 열수 추출물 $100 \mu \mathrm{g} / \mathrm{ml}$ 가 collagen 합성에 가장 효율 적인 영향을 미치는 것으로 나타났다.

ROS (Reactive oxygen species) 생성에 대한 영향

활성산소(ROS)는 산소의 환원 대사물로서 정상 세포 내 대 사 과정이나 세포질 내 효소 작용에 의해 내부로부터 형성되 거나 다양한 외부 요소에 의해 형성된다. 세포들은 ROS의 축
적과 손상에 대항하기 위해 항산화 방어기전을 갖추고 있는 데, ROS 발생이 세포의 항산화 능력을 초과하는 경우 산화적 스트레스에 노출된다[3].

최근 연구에서는 산화적 스트레스와 골질환의 연관성도 보 고가 되고 있는데, 골다공증 여성의 경우는 혈중 항산화제 농 도가 감소되었다는[23] 연구와 항산화 비타민 섭취로 인해 골 밀도가 증가되었다는[19] 연구가 보고되고 있다. 또한 본 연구 에 사용된 MC3T3-E1 세포에 $\mathrm{H}_{2} \mathrm{O}_{2}$ 를 첨가한 결과 조골세포의 


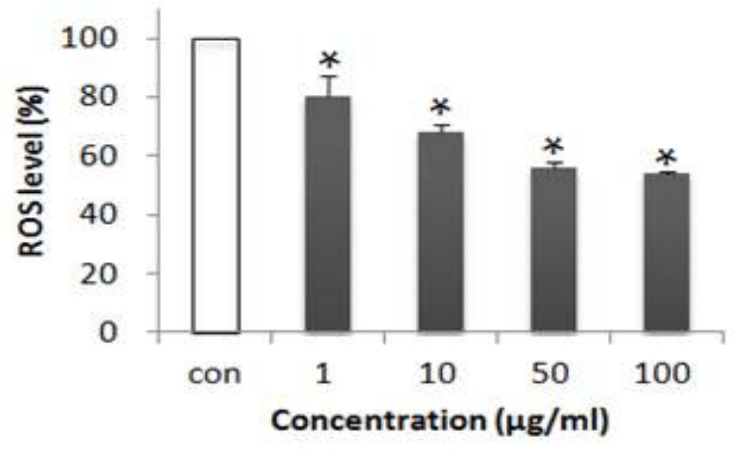

(a) $\mathrm{OH}-\mathrm{SeW}$

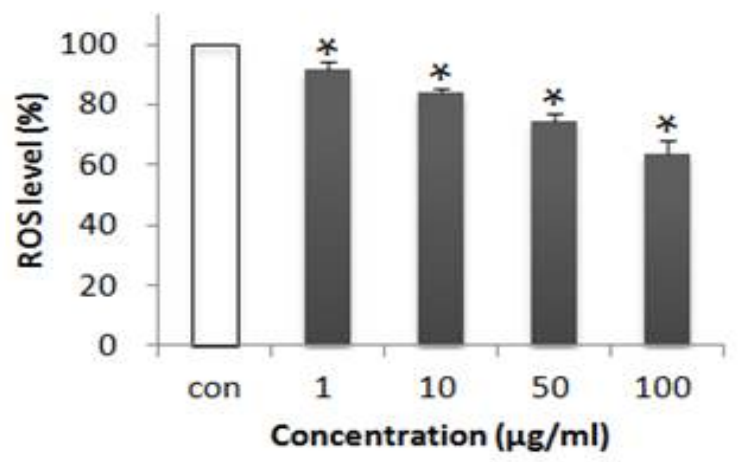

(c) OH-PW

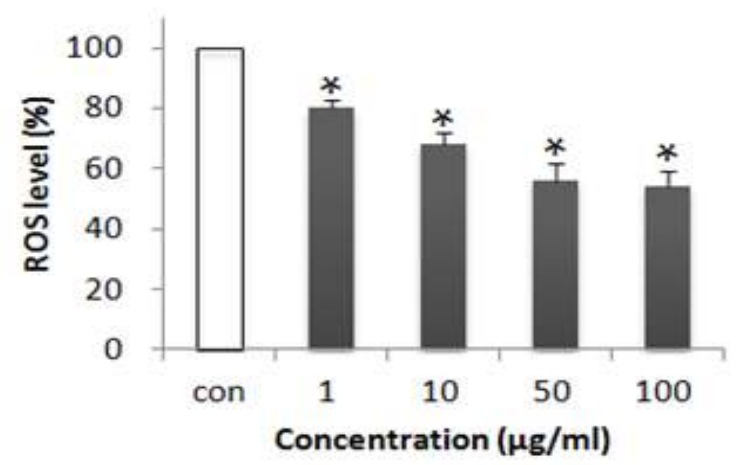

(e) OH-StW

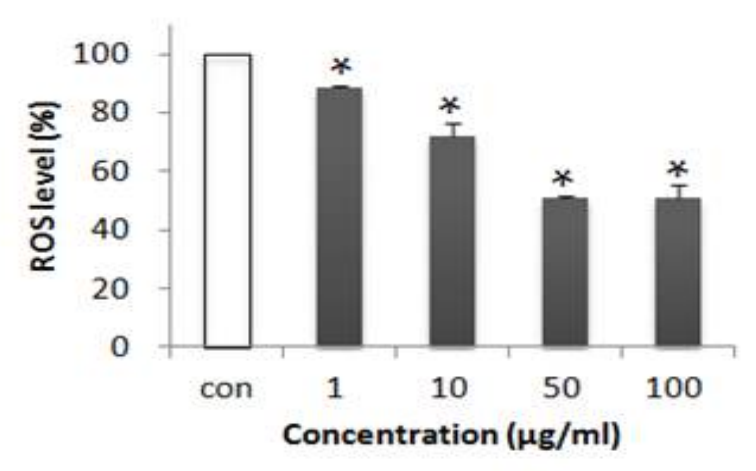

(b) OH-SeE

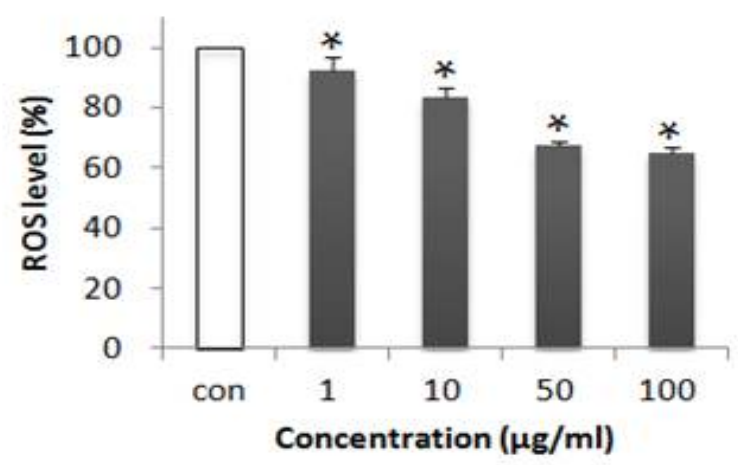

(d) OH-PE

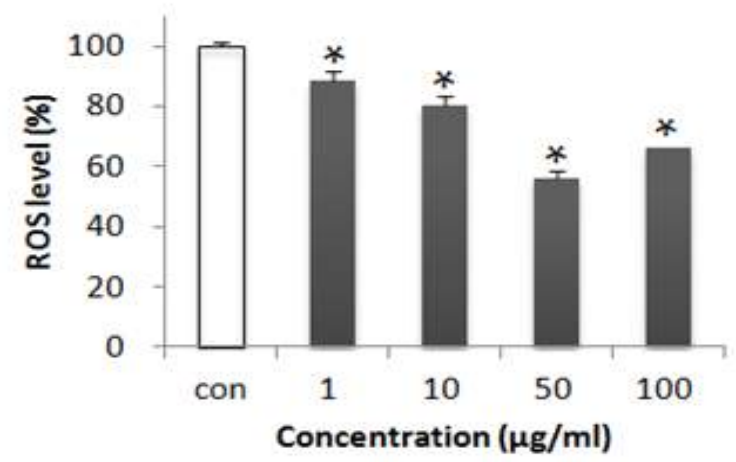

(f) OH-StE

Fig. 4. Reactive oxygen species (ROS) scavenging activities of hot water and ethanol extracts of Opuntia humifusa. Data were expressed as percentage of control.Con; Opuntia humifusa extracts $0 \mu \mathrm{g} / \mathrm{ml},{ }^{*} p<0.05$ compared with control.

분화를 저해하였다는[26] 연구와 산화적 스트레스로 인한 조 골세포의 저해는 항산화제의 첨가로 차단되었다[28]는 연구도 보고되었다.

$0.3 \mathrm{mM} \mathrm{H} \mathrm{O}_{2}$ 투여 후의 조골세포 내의 $\mathrm{ROS}$ 생성 수준 은 천년초 추출물 처리에 의해 농도 의존적으로 형광 강도 가 감소하는 경향을 보였으며, 특히 씨 열수 추출물의 $50 \mu \mathrm{g} /$ $\mathrm{ml}$ 및 $100 \mu \mathrm{g} / \mathrm{ml}$ 경우는 대조군에 비해 $50 \%$ 정도 ROS가 생성된 것을 확인 할 수 있었다(Fig. 4). 따라서 천년초 씨 추출물이 세포 내에서 높은 항산화력을 나타내는 것을 확인
할 수 있었다.

활성산소(ROS)는 생체세포를 공격하여 DNA, RNA를 파괴 하는 등 암을 발생시키고 노화를 촉진시키지만 한편으로는 병원체나 이물질을 제거하기 위한 생체 방어 과정에서 $\mathrm{O}_{2}$, $\mathrm{H}_{2} \mathrm{O}_{2}$ 와 같은 활성산소가 대량 발생하여 이들의 강한 살균작 용을 통해 병원체로부터 인체를 보호하는 양면성을 가지므로 [16] 이의 상관관계에 따른 추가적인 연구가 필요하다고 사료 된다. 


\section{References}

1. Arlot, M., P. J. Meunier, G. Boivin, L. Haddock, J. Tamayo, R. Correa-Rotter, S. Jasqui, D. W. Donley, G. P. Dalsky, J. S. Martin, and E. F. Eriksen. 2005. Differential effects of teriparatide and alendronate on bone remodeling in postmenopausal women assessed by histomorphometric parameters. J. Bone Miner. Res. 20, 1244-1253.

2. Barr, S. J. and H. A. McKay. 1988. Nutrition, Exercise, and bone status in youth. Int. J. Sport Nutr. 8, 124-142.

3. Beckman, K. B. and B. N. Ames. 1998. The free radicaltheory ofaging matures. Physiol. Reviews 78, 547-581.

4. Canalis, E. 1983. The hormonal and local regulation of bone formation. Endocr. Rev. 4, 62-77.

5. Canalis, E. 1985. Effect of growth factors on bone cell replication and differentiation. Clin. Orthop. Related Res. 193, 246-263.

6. Centrella, M., T. L. Mcartht, and E. Canalis. 1987. Transforming growth factor B is a bifunctional regulator of replication and collagen synthesis in osteoblast-enriched cell cultures from fatal rat bone. J. Biol. Chem 262, 2869-2874.

7. Cho, G. J. 2010. Health Insurance Review \& Assessment Service. South Korea.

8. Dragsted, L. O., M. Strube, and J. C. Larsen. 1993. Cancer-protective factor in fruits and vegetables. Biocheminal and biological background. Pharmacol. Toxicol. 72, 116-135.

9. Herrision, G., I. M. Shapiro, and E. Golub. 1995. The phosphatidylinositol-glycolipid anchor on alkaline phosphatase facilitates mineralization initiation in vitro. J. Bone Miner. Res. 10, 568-573.

10. Jang, Y. J. 2008. Effects of Acanthopanax senticosus vat. Subinermis (ASVS) leaf extract on promoting cell proliferation, differentiation, mineralization and osteogenesis-related gene expression in ROS 17/2.8 cells. Department of Food and Nutrition. M. S. thesis, Graduate School of Younsei University, Korea.

11. Jeon, M. H. 2011. Effect of Hijkia fusiforme fractions on proliferation and differentiation in osteoblastic MC3T3-E1 cells. J. Life Sci. 21, 300-308.

12. Kang, S. R. 2009. Effect of ecklonia cava extracts on lipids and bone turnover markers in menopausal women. $M . S$. Thesis, Graduate School of Silla University, Korea.

13. Katagiri, T. and N. Takahashi. 2002. Regulatory mechanisms of osteoblast and osteoclast differentiation. Oral Diseases 8, 147-159.

14. Kimble, R. B., J. L. Vannice, and D. C. Bloedow. 1994. Interleukin-I receptor antagocist decrease bone loss and resorption in ovariectomized rats. J. Clin. Invest 93, 1959-1967.

15. Kim, D. J., J. H. Jung, S. G. Kim, H. K. Lee, and S. K. Lee. 2011. Antioxidants and anti-obesity activities of hot water and ethanolic extracts from Cheonnyuncho (Opuntia humifusa). Korean J. Food Preserv 18, 366-373

16. Kim, K. A. 2004. Reactive oxygen species scavenging activity of salicornia herbacea extracts and its application to cosmetics. M. S. Thesis, Graduate School of Seoul National
University of Science and Technology, Korea.

17. Kim, M. J. 2008. Physicochemical characteristics of Jeungpyun by different addition ratios of prickly pear powder during storage. M. S. Thesis, Sungshin Women's University, Korea.

18. Kim, M. J., N. K. Im, M. H. Yu, H. J. Kim, and I. S. Lee. 2011. Effects of extracts from sarcocarp, peels, and seeds of avocado on osteoblast differentiation and osteoclast formation. J. Korean Soc. Food Sci. Nutr. 40, 919-927.

19. Kinoshita, T., M. Shirouzu, A. Kamiya, K. Hashimoto, S. Yokoyama, and A. Miyajima. 1997. Raf/MAPK and rapamycin-sensitive pathways mediate the anti-apoptotic function of p21Ras in IL-3-dependent hematopoietic cells. Oncogene 15, 619-627.

20. Lee, J. R. 1995. Effects of Cytokines on the Ostoeblastic Cells in Culture. M. S. Thesis, Graduate School of Dankook University, Korea.

21. Lee, J. W. 2004. Effect of Solidago Virga-aurea var. giagantea Mig. Root extract on the activity of osteoblastic cells and bone metabolism. M. S. Thesis, Graduate School of Keimyung University, Korea.

22. Lee, K. S. 2004. Antioxidant, Antimicrobial Effect of the Extracts of Cactus Cheonnyuncho (Opuntia humifusa) and Identification of Activity Substance. M. S. Thesis, Graduate School of Hoseo University, Korea.

23. Lee, N. Y., Jo, C. R., Byun, M. W. 2005. Application of irradiation technology for development of functional natural materials. Food Industry and Nutrition 10, 26-31.

24. Lee, Y. S. 2001. Effect of isoflavones on proliferation and oxidative stress of MC3T3-E1 osteoclast-like cells. Korea Soybean Digest 18, 35-42.

25. Manolagas, S. C. 2000. Basic regulatory mechanisms and implications for the pathogenesis and treatment of osteoporosis. Birth and death of bone cells. Endocr. Rev. 21, 115-137.

26. Mody, L., F. Parami, T. A. Sarafian, and L. L. Demer. 2001. Oxidative stress modulates osteoblastic differentiation of vascular and bone cell. Free Rad Biol. Med 31, 509-519.

27. Mone, Z. 2007. Skeletal remodeling in health and disease. Nat. Med 13, 791-801.

28. Nicholson, N. C., W. K. Ramp, J. S. Kneisl, and K. K. Kaysinger. 1998. Hydrogen peroxide inhibits giant cell tumer and osteoblast metabolism in vitro. Clin. Orthop. 347, 250-260.

29. Nijweide, P. J., E. H. Burger, and J. H. Feyen. 1986. Cells of bone: proliferation, differentiation, and hormonal regulation. Physiol. Rev. 66, 855-886.

30. Noriyoshi, K., I. Seichi, K. Mamoru, H. Yoshiyuki, I. Katsumi, and K. Masuoshi. 1986. Effect of 1,25-dihydroxyvitamin $\mathrm{D}_{3}$ on osteoblastic MC3T3-E1 cell. Endocrinology 118, 940-947.

31. Owen, T. A., M. Aronow, and V. Shahoub. 1990. Progressive development of the rat osteoblast phenotype in vitro. relationships in expression of genes associated with osteoblast proliferation and differentiation during formation of the bone extracellular matrix. J. Cell Physiol. 143, 420-430.

32. Park, J. C., H. J. Gwon, S. S. Kim, J. S. Chun, and J. W. 
Choi. 2000. Effects of phloroglycinol isolated from Ecklonia stolonifera on the acetaminophen-Metabolizing enzyme system in rat. J. Korea Soc. Food Sci. Nutr. 29, 448-452.

33. Park, M. K., Y. J. Lee, and E. S. Kang. 2005. Hepatoprotective effect of Cheonnyuncho (Opuntia humifusa) extract in ats treated carbon tetrachloride. Korean J. Food Sci. Technol. 37, $822-826$

34. Row, S. M., S. T. Jung, and J. Y. Lee. 1997. "Epidemiology of osteoporosis in Korea". Osteoporosis International. 7, 88-90.

35. Shin, J. M., C. K. Park, E. Shin, T. H. Jo, and J. K. Hwagn. 2008. Effects of Scutellaria radix extract on osteoblast differentiation and osteoclast formation. Korean J. Food Sci. Technol. 40, 674-679.

36. Stein, G. S., J. B. Lian, A. J. Van Wifnen, and M. Montechino.
1996. Transcriptional control of osteoblast growth and differentiation. Physiol. Rew. 76, 593-629.

37. Yoon, H. G., T. Woo, J. W. Kim, Y. S. Kim, K. Y. Kim, Y. K. Choi, and K. S. Seo. 1993. Osteoblastic cell line MC3T3-E1 cell to the triiodothyronine. Korean J. Medicine. 44, 49-58.

38. Yoon J, A. and Y, S. Son. 2009. Effects of Opuntia ficus-indica complexes B (OCB) on blood glucose and lipid metabolism in streptozotocin-induced diabeticrats. Korean J. Food and Nutr. 22, 48-56.

39. Yoon, M. S. 2010. Effect of Irradiation and Enzyme treatment on Viscosity of Cactus Cladodes and its Some Biological Activities. M. S. Thesis, Graduate School of Chonnam University, Korea.

\section{초록 : 천년초 추출물이 조골세포의 증식과 ROS소거능에 미치는 영향}

황현정 $\cdot$ 정복미 ${ }^{2} \cdot$ 김미향**

( ${ }^{1}$ 신라대학교 식품영양학과, ${ }^{2}$ 전남대학교 식품영양학과)

우리나라에서 자생하고 있는 천년초는 새로운 생리활성 물질을 생산할 수 있는 소재로 각광받고 있으며, mouse calvaria 유래의 MC3T3-E1 세포는 골세포의 세포 활성과 관련된 연구에서 유용하게 이용되어 왔다. 따라 서 본 연구에서는 MC3T3-E1 세포를 이용하여 천년초 추출물이 세포 증식에 미치는 영향과 ALP 활성, 조골세포 의 골 형성을 위한 필수 인자인 collagen 합성에 대한 영향을 검토하고 세포사의 주요 인자인 ROS 에 미치는 영향에 대해 검토하였다. 각 추출물의 수율은 껍질 열수 추출물이 $35.2 \%$ 로 가장 수율이 높았고, 다음으로 줄기 열수 추출물, 껍질 에탄올 추출물, 씨 열수 추출물, 줄기 에탄올 추출물 순으로 나타났으며, 수율이 가장 낮은 씨 에탄올 추출물은 $20.6 \%$ 였다. 각 추출물의 농도 $(1,1050,100 \mathrm{\mu g} / \mathrm{ml})$ 에 따른 조골세포 성장에 미치는 영향을 MTT assay로 분석한 결과, 모든 군에서 대조군과 비교하여 유의적인 증식률을 나타내었으며 특히, $100 \mu \mathrm{g} / \mathrm{ml}$ 씨 열수 추출물을 첨가하였을 때, 대조군과 비교하여 가장 높은 $120 \%$ 정도의 증식률을 나타내었다. 천년초 추출 물이 ALP 활성에 미치는 영향을 조사한 결과, 천년초 추출물을 $10 ~ 50 \mathrm{\mu g} / \mathrm{ml}$ 첨가하였을 때, 대조군과 비교하여 유의적으로 증가하였으며 특히, 씨 에탄올 추출물을 $50 \mathrm{\mu g} / \mathrm{ml}$ 첨가하였을 때, $130 \%$ 이상의 ALP 활성을 증가시 켜 조골세포의 분화에 영향을 줄 가능성이 제시 되었다. 천년초 추출물이 조골세포의 collagen 합성에 미치는 실 험결과에서는 천년초 씨 열수 추출물과 씨 에탄올 추출물의 $50 ~ 100 \mu \mathrm{g} / \mathrm{ml}$ 농도에서 높은 합성능을 나타내었으 며 그 중 씨 열수 추출물 $100 \mathrm{\mu g} / \mathrm{ml}$ 농도에서 가장 높은 collagen 합성능을 보였다. 천년초 추출물이 세포내 ROS 생성에 미치는 영향을 실험한 결과에서는 모든 천년초 추출물 처리에 의해 농도 의존적으로 형광 강도가 감소하 는 경향을 보였으며 특히, 씨 열수 추출물의 $100 \mu \mathrm{g} / \mathrm{ml}$ 경우, 대조군에 비해 $54 \%$ 정도 ROS가 감소되어 천년초 씨 추출물이 세포 내에서 높은 항산화력이 있는 것을 확인할 수 있었다. 따라서 천년초 추출물이 조골세포의 증 식, ALP 활성, collagen 합성 및 ROS 생성 저해를 촉진하여 골 생성에 영향을 줄 수 있는 것이 확인되었으며, 추출 용매와 관계없이 씨 추출물이 가장 높은 활성을 나타내었다. 천년초 씨 중의 활성 성분 구명을 위해 향후 구체적 기작 연구와 in vivo 연구가 병행된다면, 골다공증 예방과 관련된 기능성 식품의 천연소재 개발이 가능할 것이라 사료된다. 